\title{
UPAYA PENINGKATAN KREATIVITAS BELAJAR SISWA MENGGUNAKAN METODE TANYA JAWAB PADA MATA PELAJARAN TEMATIK
}

\author{
Titi Sukamti ${ }^{1}$ \\ SDN 4 Sritejokencono Kota Gajah Lampung Tengah \\ Email: Prasetyo.ad.n@gmail.com
}

\begin{abstract}
This research is intended as one of the efforts to improve students' learning creativity using question and answer method on thematic subjects class iii sdn4 sritejokencono kecamatan gajah kecamatan kecamatan junior high school year 2014/2015. The purpose of PTK (Classroom Action Research) is a benchmark activity to improve the quality of education conducted by teachers. In the PTK the problems that arise in the learning will be solved by the use of a method. The research looked for problem solving in the classroom by using $Q \& A$ method so that third grade students were motivated in the subject of Thematic Lesson with maximum. Step analysis is done by planning action learning, implementation of action, observation, reflection and evaluation. Research the activity through several cycles.
\end{abstract}

Keywords: Thematic, $Q \&$ A Method

\footnotetext{
${ }^{1}$ Guru SDN 4 Sritejokencono Kota Gajah Lampung Tengah
} 


\begin{abstract}
Abstrak
Penelitian ini dimaksudkan sebagai salah satu Upaya peningkatan kreativitas belajar siswa menggunakan metode tanya jawab pada mata pelajaran tematik kelas iii sdn4 sritejokencono kecamatan kota gajah kabupaten lampung tengah tahun pelajaran 2014/2015. Tujuan PTK (Penelitian Tindak Kelas) adalah kegiatan tolak ukur untuk meningkatkan mutu pendidikan yang dilakukan oleh guru. Dalam PTK masalah-masalah yang muncul dalam pembelajaran akan diselesaikan dengan penggunaan suatu metode. Penelitian mencari solusi masalah di kelas dengan menggunakan Metode Tanya Jawab agar siswa kelas III termotivasi dalam mata Pelajaran Tematik dengan maksimal. Langkah analisis dilakukan dengan perencanaan tindakan pembelajaran, pelaksanaan tindakan, observasi, refleksi dan evaluasi. Penelitian kegiatan tersebut melalui beberapa siklus.
\end{abstract}

Kata Kunci : Tematik, Metode Tanya Jawa

\title{
PENDAHULUAN
}

\section{A. LATAR BELAKANG}

Guru sebagai tenaga profesional dituntut untuk memiliki kompetensi paedagogi, kompetensi profesional, kompetensi kepribadian, dan kompetensi sosial. Upaya untuk menguasai keempat kompetensi itu melalui pendidikan formal hanyalah merupakan syarat mutlak bagi guru. Akan tetapi upaya peningkatan kemampuan terus menerus (continuous improvement) merupakan syarat yang tidak perlu ditawar-tawar lagi. Salah satu pilihan upaya yang bisa digunakan guru untuk melakukan continuous improvement adalah melalui penelitian tindakan kelas. Penelitian tindakan kelas merupakan salah satu alternatif model pembinaan profesi pendidik melalui pengkajian 
pembelajaran dalam beberapa siklus secara kolaboratif dan berkelanjutan berlandaskan prinsip-prinsip kesejawatan dan saling membutuhkan (Suharsimi Ahkunto, 2006: 23). Dengan kata lain penelitian tindakan kelas merupakan suatu cara peningkatan mutu pendidikan yang tak pernah berakhir. Dan segi profesionalisme, penelitian tindakan kelas juga dipandang sebagai suatu unjuk kerja seorang guru yang professional karena studi sistemik yang dilakukan terhadap din sendiri dianggap sebagai tanda (hallmark) dari pekerjaan guru yang professional (Hopkins, 1993 dalam Wardani, 2000).

Alasan lain yang juga ikut memperkuat perlunya guru melakukan penelitian tindakan kelas adalah keterlibatan guru dalam berbagai kegiatan pengembangan di sekolahnya dan mungkin ditingkat yang lebih luas, sehingga is perlu melakukan review terhadap kinerjanya sendiri, untuk selanjutnya dapat dipakai sebagai masukan terhadap kinerjanya sendiri, untuk selanjutnya dipakai sebagai masukan dalam reviu kinerja sekolah. kegiatan menilai daya serap, review muatan kurikulum, atau review teknik pembelajaran yang efektif memerlukan keterampilan untuk melaksanakan penelitian tindakan kelas, guru akan merasa lebih mantap berpartisipasi dalam berbagai kegiatan inovatif. Dengan kata lain penelitian tindakan kelas adalah suatu tindakan perbaikan pembelajaran yang memerlukan kompetensi secara komperhensif.

Untuk itulah dan melalui program pendidikan sarjana guru sekolah dasar Universitas Terbuka yang program akhirnya adalah menyusun laporan penelitian tindakan kelas dalam mata 
kuliah Pemantapan Kemampuan Profesional (PKP) peneliti melakukan penelitian tindakan kelas. Penelitian tindakan kelas yang dilakukan peneliti diarahkan pada mata pelajaran Tematik.

\section{Tujuan Penelitian}

Kegiatan perbaikan pembelajaran yang penulis laksanakan bertujuan untuk mengetahui apakah model pembelajaran menggunakan metode tanya jawab dapat meningkatkan kreativitas belajar siswa pada mata pelajaran tematik kelas III SDN 4 Sritejokencono Kecamatan Kota Gajah Tahun Pelajaran 2014/2015.

\section{B. LANDASAN TEORI}

\section{Hakikat Belajar}

Pendapat dan Winkel (1991: 53) mengatakan bahwa: "Belajar merupakan suatu aktivitas mental atau psikis yang berlangsung dalam interaksi aktif dengan lingkungan yang menghasilkan perubahan-peruhahan dalam pengetahuan, pemahaman, keterampilan, nilai dan sikap yang dimiliki oleh suatu individu". Sedangkan Sardiman (1994:45) mengartikan belajar sebagai suatu proses yang kompleks yang terjadi pada semua orang dan berlangsungnya seumur hidup.

Nasution (1989: 45) mengemukakan bahwa belajar adalah suatu proses. Melalui proses tersebut, seseorang mengubah tingkah lakunya dengan cara latihan, baik latihan yang dipersiapkan secara khusus di laboratorium maupun latihan yang terjadi secara alamiah, dimana individu berinteraksi dengan lingkunganya. 
Dapat dikemukakan beberapa prinsip yang berkaitan dengan belajar, yaitu:

1. Belajar pada hakikatnya potensi manusia dan perilakunya.

2. Memerlukan proses dan penahapan serta kematangan diri para siswanya.

3. Belajar akan lebih mantap dan efektif apabila didorong motivasi, perkembangan pengalaman siswa yang akan banyak mempengaruhi hasilbelajarnya

\section{Kreativitas}

Menurut Utami Munandar (1987) dalam bukunya mengenai pengembangan bakat dan kreatifitas anak sekolah, ada beberapa kriteria pengertian tentang kreatifitas berdasarkan pendapat pare ahli yang juga merupakan pengertian dasar dari kreatifitas adalah bahwa kreatifitas merupakan kemampuan untuk membuat kombinasi baru berdasarkan data, informasi dan unsur-unsur yang ada. Pada umumnya, orang mengartikan kereatifitas sebagai daya cipta, khususnya menciptakan hal-hal baru. Sebetulnya kreatifitas tidak hares menciptakan sesuatu yang benar-benar baru, tetapi dapat juga merupakan gabungan atau kombinasi spa yang sudah ada sebelumnya. Apa yang diciptakan dapat diperoleh dad sekolah maupun lingkungan keluarganya. Dengan demikian semakin memperbesar kemungkinan untuk menciptakan ide-ide yang dihasilkan.

Menurut Rosemini (2000), jika ditinjau dari belahan otak manusia yang terdiri dari belahan otak kanan dan belahan otak kiri, tampak bahwa masing-masing memiliki kekhususan tersendiri. Belahan otak kiri yang banyak mengontrol bagian kanan tubuh manusia, ternyata banyak didalam lingkungan 
budaya cenderung memiliki dominan dan lebih dikembangkan. khususnya begitu anak mulai masuk sekolah. Belahan otak kiri banyak berkaitan dengan verbal, matematis, analitis, rasional, serta menekan pada hal-hal yang beraturan Sedangkan belahan otak kanan yang mengontrol bagian kiri tubuh manusia, mengkhususkan terutama pada hal-hal yang bernon verbal dan holistik intuitif, imajinatif. Agar kreatifitas seseorang lebih terwujud, maka belahan otak kanan perlu di asah.

Utami Munandar (1999) dan Rosemini (2000), tentang kreatifitas menurut konsep, merupakan suatu pendekatan yang melihat kreatifitas dari segi pribadi, pendorong, proses dan produk kreatifitas. Sebagai pribadi menunjukkan bahwa kreatifitas pasti dimiliki setiap orang, namun dengan keadaan yang berbeda-becla Sebagia pendorong dapat diartikan lingkungan memiliki andil dalam memberikan rangsangan sehingga kreatifitas dapat terwujud. Proses adalah sesuatu yang diperlukan, untuk melihat bagaimana suatu hasil yang kreatif seseorang diharapkan dapat dinikmati oleh lingkungan dan yang lebih penting, hasil kreatif seseorang harus bermakna bagi yang bersangkutan

\section{Motivasi}

- Menurut Hull (1943), motivasi berfungsi sebagai dorongan untuk memenuhi atau memuaskan kebutuhan.

- Menurut teori kognitif (Drs. Suciati, dkk) menjelaskan motivasi sebagai fungsi dinamika psikologis perilaku manusia yang lebih kompleks, motivasi tidak saja merupakan fungsi pemenuhan kebutuhan tetapi dipahami sebagai kerangka pikir yang melibatkan kebutuhan, tujuan, 
sistem, nilai persepsi pribadi dan pengalaman.

Menurut teori behavionsme, motivasi sebagai fungsi rangsangan (stimulus) dan respon

\section{METODE PENELITIAN}

\section{a. Subyek Penelitian}

\section{Lokasi / Tempat}

Tempat pelaksanaan perbaikan pembelajaran adalah di Sekolah Dasar Negeri 4 Sritejokencono Kecamatan Kota Gajah Kabupaten Lampung Tengah. Kelas III pada mata pelajaran tematik.

\section{Kelas}

Kelas III (tiga) terdiri dari 18 orang siswa (9 siswa laki-laki dan 9 siswa perempuan).

\section{Waktu}

Waktu pelaksanaan pembelajaran adalah mulai dan tanggal 16 April s/d 16 Mei 2015 dengan rincian jadwal sebagai berikut :

\section{Jadwal Pelajaran}

\begin{tabular}{|l|l|l|l|}
\hline Siklus ke & Mata Pelajaran & Hari dan Tanggal & Jam ke \\
\hline I & Matematika & Selasa, 16 April 2015 & $1-2$ \\
\hline I & Matematika & Senin, 22 April 2015 & $3-4$ \\
\hline II & Matematika & Kamis, 16 Mei 2015 & $1-2$ \\
\hline
\end{tabular}

\section{b. Desain Prosedur Perbaikan Pembelajaran}

Kegiatan perbaikan pembelajaran matematika untuk konsep operasi hitung pecahan, dilaksanakan dalam dua siklus pembelajaran yang meliputi kegiatan perencanaan, tindakan, pengamatan dan refleksi. Pada setiap siklus perbaikan, penulis 
dibantu oleh guru SDN 4 Sritejokencono Kecamatan Kota Gajah yang selanjutnya pada laporan ini disebut tim peneliti. Berikut deskripsi dari setiap prosedur kegiatannya :

\section{Perencanaan}

\section{Siklus I}

- Merencanakan jumlah siklus yang akan dilaksanakan

- Mempersiapkan rencana pembelajaran

- Menetapkan alat evaluasi, lembar kerja

- Membuat lembar kerja observasi siswa

- Menganalisis hasil pelajaran

\section{Siklus II}

- Menetapkan hal-hal yang akan diperbaiki

- Menyusun rencana pembelajaran perbaikan

- Menetapkan alat evaluasi

- Menyiapkan lembar kerja siswa

- Melaksanakan kegiatan perbaikan pembelajaran

- Mengambil data kegiatan pembelajaran dan menganalisis data tersebut.

\section{Siklus III}

- Menetapkan hal-hal yang akan diperbaiki

- Menyusun rencana pembelajaran 2

- Menyiapkan sumber belajar dan referensinya

- Menyiapkan alat evaluasi

- Melaksanakan kegiatan pembelajaran 2

- Mengumpulkan data dan menganalisis data 
Perencanaan perbaikan tersebut diatas dilakukan untuk mata pelajaran matematika dengan menitik beratkan kepada pengguna metode tanya jawab kepada siswa untuk meningkatkan prestasi belajar siswa pada pembelajaran.

\section{Pelaksanaan}

Dalam melaksanakan Pemantapan Kemampuan Profesional, sejumlah kegiatan harus dilakukan berulangulang mulai dari tahap orientasi pelaksanaan, tahap observasi, refleksi dan revisi merupakan serangkaian persiapan pelaksanaan. Adapun langkah-langkah yang ditempuh penulis dalam perbaikan pembelajaran matematika adalah sebagai berikut :

a. Melakukan penggalian pengetahuan siswa pada awal kegiatan sebagai masukan pengetahuan untuk mengetahui sampai dimana pengetahuan yang telah dikuasai siswa

b. Mengkonfirmasi tujuan pembelajaran sehingga maksudnya agar arah pembelajaran dapat dikuasai dan dimengerti oleh siswa.

c. Diskusi secara berkelompok membahas latihan-latihan yang diberikan dengan cara memperagakan suatu kasus atau masalah.

d. Diskusi secara klasikal dengan peragaan per kelompok untuk suatu masalah, kemudian kelompok lain memberikan tanggapan.

e. Memberikan kesempatan kepada siswa lain untuk mencatat rangkuman pelajaran yang telah dipelajari

f. Menyimpulkan materi pelajaran 
g. Memberikan latihan-latihan dengan metode pekerjaan rumah kepada siswa.

\section{Pengamatan}

Pelaksanaan perbaikan pembelajaran ini dilakukan penulis dari tanggal 16 April s/d 16 Mei 2015, untuk mata pelajaran Matematika dengan jumlah siklus sebanyak 3 siklus.

Pada siklus I, langkah yang ditempuh adalah melakukan pembelajaran secara umum. Pada siklus ini penulis melakukan tatap muka sebagai dasar untuk dapat mengetahui sejauhmana tingkat kreatifitas dan kemajuan prestasi siswa setelah diberikan latihan-latihan dengan menggunakan metode pemberian pekerjaan rumah. Setelah diketahui hasil dari siklus I, maka siklus II merupakan pembelajaran perbaikan. Perbaikan pertama merupakan perbaikan pembelajaran, sedangkan hasil pembelajaran siklus I dilanjutkan pada siklus II. Perbaikan kedua merupakan perbaikan pembelajaran. Hasil pembelajaran siklus II dan dilaksanakan pada siklus III Pada siklus II, dalam pelaksanaannya penulis menitik beratkan pada penggunaan metode pemberian pekerjaan rumah untuk meningkatkan prestasi belajar siswa.

Dari ketiga siklus tersebut, dapat digambarkan sebagai berikut: 


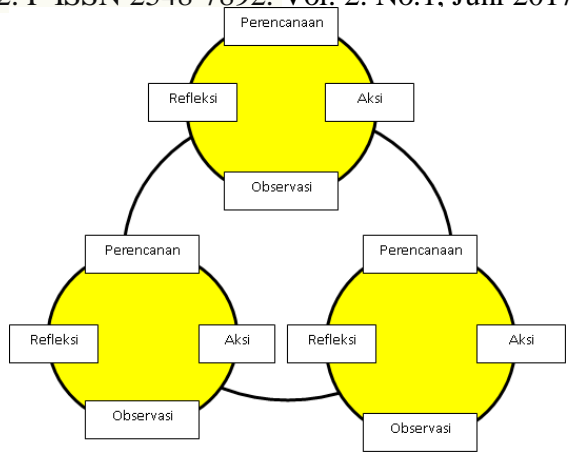

\section{Gambar 1. Siklus Penelitian Tindakan Kelas}

\section{Keterangan :}

$\mathrm{P}$ : Perencanakan
A : Aksi
O : Observasi
$\mathrm{R}$ : Refleksi

(Andayani, 2007)

\section{Pengumpulan Data}

Untuk pelaksanaan pengumpulan data, penulis menggunakan teknik tes tertulis kepada siswa sebagai teknik pokok dalam penelitian ini. Dari pemberian tes kepada siswa tersebut, dihasilkan suatu hasil sebagai berikut:

Hasil rendah 30\%, Hasil sedang 45\%, dan hasil tinggi $25 \%$.

\section{c. Data dan Sumber Data}

1. Jenis data

\section{a. Data kuantitatif}

Jenis data yang didapatkan adalah data kuantitatif pemahaman belajar siswa kelas III yang diambil dengan cara memberikan tes evaluasi pada setiap akhir siklus. 
b. Data kualitatif

Data kualitatif didapatkan dari aktifitas belajar siswa dan aktifitas guru dalam kegiatan belajar mengajar.

2. Sumber Data

Dalam penelitian tindakan kelas ini sumber datanya adalah:

a. Siswa kelas III SDN 4 Sritejokenconp.

b. Guru Kelas III SDN 4 Sritejokencono.

c. Data dokumen meliputi daftar nilai kelas III, aktifitas siswa dalam kegiatan pembelajaran serta aktifitas guru dalam kegiatan pembelajaran.

\section{d. Teknik Pengumpulan Data}

Pengumpulan data dalam PTK seperti pada umumnya suatu penelitian adalah dengan menggunakan instrumen. Instrumen memegang peranan yang sangat strategis dan penting dalam menentukan kualitas suatu penelitian, karena validitas data yang diperoleh akan sangat menentukan mutu instrumen yang digunakan. Pengambillan data dilakukan dengan wawancara, observasi, dokumentasi, tes, dan catatan lapangan.

\section{Wawancara}

Kunandar (2011: 157) menyatakan bahwa wawancara merupakan pertanyaan - pertanyaan yang diajukan secara verbal kepada orang- orang yang dianggap dapat memberikan informasi atau penjelasan dalam permasalahan penelitian tindakan kelas. 


\section{Observasi}

Observasi dilakukan dengan mengamati secara langsung kondisi dan peristiwa yang terjadi saat penelitian. Pengamatan dilakukan saat peneliti melakukan kegiatan pembelajaran yang dibantu oleh guru kelas III sebagai observer. Dan peneliti sendiri mengamati perilaku siswa di dalam dan di luar kelas

3. Dokumentasi

Dokumentasi bertujuan untuk memperoleh atau mengetahui sesuatu dengan buku-buku, arsip yang berhubungan

\section{e. Validitas Data}

Agar Instrumen yang dibuat oleh peneliti dapat dikatakan valid maka dilakukan validitas. Validitas dalam penelitian ini dilakukan dengan diuji dan diperiksa dulu validitasnya, sehingga data tersebut dapat dipertanggung jawabkan. Untuk menjamin validitas ini maka semua pertanyaan disusun berdasarkan kajian-kajian teori yang berkaitan dengan permasalahan.

Peneliti menggunakan 2 jenis trianggulasi yaitu trianggulasi sumber dan trianggulasi waktu. Trianggulasi sumber merupakan teknik pengumpulan data yang sejenis dari berbagai sumber data yang berbeda. Maksudnya data tersebut dilakukan ricek kebenarannya dari sumber lain yang dianggap paham dengan data. Trianggulasi waktu artinya data tersebut dicek pada respondent pertama pada waktu yang berbeda (Rubino R. \& Saring M. : 2008:60). 


\section{f. Teknik Analisis Data}

Untuk melihat aktivitas siswa selama proses pembelajaran maka dilakukan pengamatan-pengamatan yang dicatat dalam lembar observasi aktivitas belajar. Untuk menghitung jumlah siswa yang beraktivitas menggunakan rumus sebagai berikut:

$P=\frac{\sum X}{n} x 100 \%$

Keterangan :

$P \quad=$ Persentase

$\Sigma \mathrm{X}=$ Jumlah siswa yang aktif

$\mathrm{n} \quad=$ Jumlah siswa. (Edi Kusnadi, 2008: 102)

dengan data. Trianggulasi waktu artinya data tersebut dicek pada respondent pertama pada waktu yang berbeda (Rubino R. \& Saring M. : 2008:60).

\section{g. Teknik Analisis Data}

Untuk melihat aktivitas siswa selama proses pembelajaran maka dilakukan pengamatan-pengamatan yang dicatat dalam lembar observasi aktivitas belajar. Untuk menghitung jumlah siswa yang beraktivitas menggunakan rumus sebagai berikut: $P=\frac{\sum X}{n} x 100 \%$

Keterangan :

$P \quad=$ Persentase

$\Sigma \mathrm{X}=$ Jumlah siswa yang aktif

$\mathrm{n} \quad=$ Jumlah siswa. (Edi Kusnadi, 2008: 102) 


\section{HASIL PENELITIAN}

Berdasarkan data-data di atas temuan yang cukup menarik dari pembelajaran siklus I adalah rata-rata nilai siswa meningkat 63 dibandingkan pembelajaran sebelumnya namun masih ada beberapa siswa yang belum mencapai nilai KKM. Ada sebanyak 12 siswa (80\%) tuntas belajar dan 6 siswa (20\%). Apabila dikomparasi dengan hasil observasi rekan sejawat maka penyebabnya bukan pada model pendekatan pembelajaran dan alat peraga yang digunakan tetapi dari cara guru menjelaskan, latihan dan contoh yang kurang dan desain sistematika penyajian. Dengan kata lain teori belajar yang melandasi penggunaan metode ini memang terbukti dapat meningkatkan keberhasilan siswa dalam pembelajaran.

Melihat hal tersebut tidak salah kiranya tim peneliti merekomendasikan agar cara menjelaskan guru diperbaiki dimana mengurangi istilah-istilah yang tidak dimengerti siswa, menggunakan ilustrasi-ilustrasi, diucapkan ulang pada bagian penting materi. Dan rekomendasi yang penting adalah perubahan pada kegiatan awal dimana pembelajaran dikaitkan dengan konsep yang sudah dipelajari anak sesuai dengan penerapan metode tanya jawab. Sehingga hasil belajar siklus II meningkatkan kembali rata-rata nilai siswa menjadi 65. Hasil belajar pada siklus II terdapat sebanyak 4 siswa (12\%) belum tuntas belajar dan 14 siswa (88\%) tuntas belajar.

Berdasarkan data-data di atas temuan yang cukup menarik dari pembelajaran siklus III adalah rata-rata nilai siswa meningkat 70 dibandingkan pembelajaran sebelumnya namun masih ada 
beberapa siswa yang belum mencapai nilai KKM. Terlihat pada siklus III mengalami peningkatan ada sebanyak 16 siswa (93\%) tuntas belajar dan 2 siswa (7\%). Apabila dikomparasi dengan hasil observasi rekan sejawat maka penyebabnya bukan pada metode pembelajaran yang digunakan tetapi dari cara guru menjelaskan, latihan dan contoh yang kurang dan desain sistematika penyajian. Dengan kata lain teori belajar yang melandasi penggunaan metode tanya jawab ini memang terbukti dapat meningkatkan keberhasilan siswa dalam pembelajaran.

\section{E. KESIMPULAN}

Kesimpulan-kesimpulan yang diperoleh dari kegiatan perbaikan pembelajaran ini adalah:

1. Berdasarkan data-data di atas temuan yang cukup menarik dari pembelajaran siklus I adalah rata-rata nilai siswa meningkat 63 dibandingkan pembelajaran sebelumnya namun masih ada beberapa siswa yang belum mencapai nilai KKM. Ada sebanyak 12 siswa (80\%) tuntas belajar dan 6 siswa (20\%).

2. Pada siklus II hasil belajar meningkatkan rata-rata nilai siswa menjadi 65 Hasil belajar pada siklus II terdapat sebanyak 4 siswa (12\%) belum tuntas belajar dan 14 siswa $(88 \%)$ tuntas belajar.

3. Berdasarkan data-data di atas temuan yang cukup menarik dari pembelajaran siklus III adalah rata-rata nilai siswa meningkat 70 dibandingkan pembelajaran sebelumnya namun masih ada beberapa siswa yang belum mencapai nilai KKM. Terlihat pada siklus III mengalami peningkatan 
ada sebanyak 16 siswa (93\%) tuntas belajar dan 2 siswa (7\%). Apabila dikomparasi dengan hasil observasi rekan sejawat maka penyebabnya bukan pada metode pembelajaran yang digunakan tetapi dari cara guru menjelaskan, latihan dan contoh yang kurang dan desain sistematika penyajian. Dengan kata lain teori belajar yang melandasi penggunaan metode tanya jawab ini memang terbukti dapat meningkatkan keberhasilan siswa dalam pembelajaran.

\section{F.SARAN}

1. Disarankan kepada rekan-rekan sejawat yang mengalami masalah serupa dalam pembelajaran agar melakukan pendekatansehingga pembelajaran menjadi bermakna karena siswa sendiri yang mengkonstruksi pengetahuannya.

2. Kepada Kepala Sekolah disarankan agar membuka ruang kepada guru untuk bebas berkreasi dalam melakukan kegiatan profesionalnya dan mengutamakan proses ketimbang hasil.

3. Kepada supervisor dalam hal ini pengawas TK/SD Kecamatan Kota Gajah agar selalu membuka wawasan dan mengubah pandangan guru untuk selalu menyajikan pembelajaran yang variatif dan bermakna dan efektif dalam meningkatkan hasil belajar. 


\section{DAFTAR PUSTAKA}

Amin Suyitno. 2000. Matematika Sekolah I. Semarang : UNNES.

Anonim. 1995. Kamus Bahasa Indonesia. Jakarta : Departemen Pendiddikan dan Kebudayaan.

Drs Hanif Nurcholis, MA, Drs Mafrukhi, 2005, Saya Senang Berbahasa Indonesia. Penerbit Erlangga

Dimyati. 1994. Belajar dan Pembelajaran. Jakarta Dirjen Dikti Depdikbud,

FKIP, 2007, Pemantapan Kemampuan Profesional, Edisi kesatu, Penerbit Universitas Terbuka

Haryanto, 2004, Sains SD, Penerbit Erlangga

Herman Hudoyo. 1990. Belajar Mengajar Matematika, Jakarta:

Depdikbud

IG AK. Wardani, 2003, Keterampilan Dasar Mengajar, Pusat Penerbitan Universitas Terbuka, Jakarta.

Masnur Muslich, 2007, Pembelajaran Berbasis Kompetensi dan Kontekstual, edisi kesatu cetakan ke2, Penerbit Bumi Aksara

Nana Sudjana dan Wari Suwariyah 1991. Model-Model Mengajar CBSA. Bandung: Sinar Baru

Retno. W. Endang. 2002. Metode Penelitian Kelas. Semarang : UNNES.

Sugarti. 2003. Matematika Sekolah II. Semarang : UNNES.

Suharsimi Arikunto. 1989. Dasar-dasar Evaluasi Pendidikan. Jakarta Bumi Aksara.

Tilaar, 1999. Hakekat Pendidikan: Pendidikan Anak di SD, Jakarta. Universitas Terbuka 